\title{
Only children in Poland: demographic, social, and educational consequences
}

\author{
Beata Stachowiak \\ The Political Studies and International Relations Faculty, Torun, Poland \\ Nicolaus Copernicus University, UMK, Torun, Poland
}

Email address:

Beata.Stachowiak@umk.pl (B. Stachowiak)

To cite this article:

Beata Stachowiak. Only Children in Poland: Demographic, Social, and Educational Consequences. Social Sciences. Vol. 2, No. 2, 2013, pp. 34-38. doi:10.11648/j.ss.20130202.12

\begin{abstract}
The main purpose of this article is to present the population of "only children" in Poland and address the possible effects of very low fertility for the functioning of the family, society, education system, and the only children themselves. This analysis is based primarily on statistics published by government institutions such the Central Statistical Office of Poland, Ministry of National Education, Ministry of Science and Higher Education, Ministry of Finance, etc. In Poland, as in other developed countries, a decrease in fertility can be observed. As a result, only children are a fast-growing group among children and adolescents. Due to changes to the definition of a family, the definition of an only child is also under transformation. Thus, the term "only child" can now refer to more and more people. Currently, the group of only children accounts for about $50 \%$ of all children. Data and demographic projections both for the population of only children and for fertility in Poland indicate that in the next few years the situation will worsen. This raises challenges on demographic grounds, as the substitutability of generations is not only threatened, but it is also not assured. Also, pedagogy becomes a field of trial, especially in terms of the education of children and in terms of preparing adults to be parents of an only child. New problems arise on a social basis in terms of providing care for the elderly and the functioning of pension systems. The growing population of only children also implies the need for new research in the field of social sciences and humanities.
\end{abstract}

Keywords: Only Child; Society, Poland, Demography; Pedagogy

\section{Introduction}

Leonardo da Vinci, Indira Gandhi, Elvis Presley, and Christian Andersen. In Poland, Mikołaj Rej, Agnieszka Osiecka, and Józef Korzeniowski (Joseph Conrad). What do all these people have in common? Surely they share the fact that they are all known. Some are known in history or politics, while others have left their mark in the culture. And although they represent different ages and professions, they all share one characteristic: they had no siblings. The issue of being an only child has been previously raised by psychologists, sociologists, and pedagogues. Now it has taken on particular significance, as being an only child has become widespread. However, it runs in different conditions than it did even 20 or 30 years ago. This dissimilarity is primarily determined by technological progress, cultural change, and the demographic situation.

\section{Criteria of Being an Only Child}

Who is an only child? Certainly it is any person who does not have siblings. However, the understanding of being an only child as being the only child of one's parents is inadequate. Those people who have lost their siblings in early childhood, or those that have siblings but there exists a large age difference between them, e.g., 20 years or more [1], could also be called only children. Currently, there is nothing exceptional about this: in Poland, the number of women delivering children after 40 years of age is increasing steadily, and this is not always the first offspring. Certainly, people who formally have half siblings but who are not brought up together - usually there is no relationship between them - can also be included in the group of only children. Such conditions occur when ex-spouses form new families. The group of people that meet this criterion for being an only child is growing, as for many years the number of divorces has remained at a relatively high level. In addition, divorces are correlated with the number of children in divorcing marriages. As statistical data for recent years in Poland indicate, marriages without children and marriages with one child are the ones that get divorced the 
most. In 2011, out of 64,594 adjudicated divorces, 24,402 divorces were between married couples with one child; by comparison, far fewer - only 10,889 cases - were married couples with two minor children [2]. As a result of marriages that lead to divorce and later ex-spouses forming new families, new doubts and questions arise concerning the essence of being an only child. If a child is the only child of one family, but is raised in another, patchwork family, can the child be considered an only child or not? There are no ties of kinship connecting the child with the other children, but the child is not brought up alone. These considerations lead to the conclusion that classic definitions are becoming inadequate in a new era of dynamic change involving families.

\section{Only Children in Poland: Present Condition and Demographic Fore- casts}

Being an only child is becoming prevalent. Polish families are shrinking. The scale of these phenomena is indicated by demographic indicators such as fertility rates. According to data from 2011-2013, the fertility was just 1.32, which classifies Poland as 212th in the ranking of 224 countries created by the CIA in terms of total fertility rate. Even in China, which can scarcely be called a country with a pro-birth population policy, this value -1.55 - is higher than Poland's. These data indicate that in Poland there is no substitutability of generations, which is guaranteed by a fertility rate of 2.1-2.15. In Poland's neighboring countries, the fertility rate is approximately the same: Lithuania 1.28; Czech Republic and Ukraine - 1.29; Slovakia - 1.39; Germany - 1.42; Belarus - 1.46; Russia - 1.61 [3]. Europe is the only continent on which by the year 2050 the population will be lower.

Another parameter reflecting the deepening process of shrinking families and an aging population in Poland is the comparison of people aged 0-14 years to the number of the population aged $65+$ years. Even in the mid-1960s there were 24 people aged 65 years and higher per 100 children; in 1980 this indicator amounted to 41 people; and, according to data from 2011, it reached 92. Ascribing these data to the family situation, a marriage in the mid-1960s statistically had eight grandchildren; in 2011, just two grandchildren. According to the projections of the Population Office of the United Nations, assuming a fertility rate of 1.45 for Poland, in 2050 there will be 200 people over the age of 65 per 100 children, which means that the statistical marriage will only have one grandson or granddaughter. In Poland, a growing number of only children have been recorded since 1967, when the first post-war demographic decline was been reported. Currently, nearly $50 \%$ of children in Poland are only children; what is more, in 2004 a family with one child up to the age of 24 accounted for $46.9 \%$ of families. One can only estimate the current situation in terms of the size of families, as the published data from the last population and housing census do not contain information about the structure of families in Poland.

The generalization of only children is the result of many factors: the increase in the number of women pursuing professions, shifts in the age at which marriage occurs, an increase in the number of people living in informal relationships, reproduction of the family structure by an only child, changes in the age of the birth of the first child, fear of single motherhood, and high divorce rates. There may be medical reasons for having one child, e.g., the traumatic experience of a first pregnancy and childbirth as well as health problems involving the parents. The economic situation is also indifferent for the level of fertility: in many cases, it has a decisive influence on attitudes towards reproduction. Unemployment, junk contracts, or working at minimum wage are not conducive to making decisions about parenthood. In Poland, there is no pro-birth policy. This manifests itself in the degradation of citizen's tax relief with respect to children, increased VAT on children's clothes, the lack of places in nursery schools and public kindergartens, etc. The low fertility rate is also influenced by a modern lifestyle promoted in most media, which is often associated with consumer or downright narcissistic attitudes, etc. In addition, television, the Internet, and magazines present an unrealistic picture of motherhood created from the perspective of celebrity mothers. The size of families is also affected by social development: a post-industrial society requires greater mobility from its members, which is much easier to obtain in a small family.

\section{Research on Being an Only Child in the World and in Poland}

Only children initially have not received good press. These negative stereotypes had their origins in publications from the 19th century: Granville Stanley Hall, Sigmund Freud, Alfred Adler, and others. They formulated theses that only children had problems with gender identification and independent decision-making. They even claimed that being an only child was synonymous with a disease. It was only around the middle of the 20th century that research conducted mainly by psychologists began to lead to slightly different conclusions, which depicted only children in a more favorable light. The breakthrough, however, turned out to be the work of Toni Falbo, who analyzed more than 100 studies on only children, which led her to startling (for that time) conclusions. Falbo proved that in terms of characteristics such as egoism and selfishness, only children did not differ from children with siblings. In addition, she showed that in families of $2+1$, a child had greater possibilities for intellectual development, as its needs were recognized more quickly and parents had more time and patience for a child [4]. In recent times, we have returned to the subject of being an only child, which is mainly caused by the fact that only children are a growing 
group in society.

Research on being an only child is often one of the many elements of large research projects. An example in this respect may be the "Understanding Society" project implemented by the University of Essex. This project has tested socioeconomic conditions in 40,000 households and the attitudes of people living in them. One of the research proposals regarded the state of being happy, the results of which have shown that only children feel happier than those with siblings. This is due to the fact that from an early age they do not have to compete with other children in the home and do not suffer violence from older siblings [5]. In turn, the results of the research of Douglas Downey from the period 1998-1999 indicate that, while it is true that there are some discrepancies at preschool age in social skills between only children and children with siblings, these differences disappear later on [6]. The social maladjustment of only children turns out to be a myth, not a fact. In recent years, researchers have also returned to the study on the influence of birth order on personality, i.e., the way the birth orders of a baby affects its development, personality and behavior, which indirectly determines its approach to education, and ultimately, its earning potential [7]. Only children are an extremely specific case, as they are firstborn, but at the same time the youngest children.

In Poland, there is little research on only children. This issue was not a part of the historical sociopolitical system. A few research projects that have been conducted lead to different conclusions, which usually depict only children in a bad light. Józef Rembowski found that having a sibling tempers the child in experiencing stress and frustration [8], and only children are deprived of such opportunities. A similar trend can be seen in the research results of Jan Śledzianowski, who argued that the lack of competition contributes to the fact that only children are infantile and puerile, and thus do not succeed in marriage and in later family life. They are not only worse suited to marriage, but also more dependent on parents, and advocate for a smaller number of children [9]. In turn, Maria Tyszkowa showed that only children are no different from people who have siblings in terms of ways of perceiving other people, prosocial activities, and the level of adaptation to the extrafamilial environment. They also proved to be significantly less timid and neurotic [10].

In Poland, there has still been no in-depth exploration on causes of the dominance of the $2+1$ family model. Social studies for the reproductive needs of Poles aged 18-44 years present a different picture. In 2012, up to $49 \%$ of adult Poles wanted to have two children, $25 \%$ wanted three children, and only $10 \%$ wanted one child [11]. There is no research-supported answer on why these needs are not ultimately fulfilled in the lives of the family units. There are also no studies involving only children in adult life, and especially in elderly life. The problem of whether being an only child in the context of Poland determines the way old age is experienced remains open.
To sum up, an analysis of available research results, both Polish and foreign, indicates that the lack of siblings determines an only child to some extent, but this is just one of many factors contributing to a person's life.

\section{5. "Only Children" Challenges}

\subsection{Personal and Family Challenges}

The only child, like any person, faces many challenges in life, some of which are specific and result from the family situation, such as stereotypical opinions about people not having siblings, etc. However, the basic life test for them is dealing with loneliness, which can be seen in various contexts. From the point of view of an only child, diagnosis and assessment of the state of loneliness is dependent on age and family considerations. The situation of an only child who suffers from a lack of companions to play with and is a bit overwhelmed by the adult world around it is different than the situation of a lonely, mature man without immediate family. Today, parents are more aware of this than they used to be, especially when they were only children themselves. By analyzing their own childhood experience, they support their child not only in finding companions, but also in extracurricular socialization. For example, in the United States parents of only children formed a support group for their little ones and organized weekly meetings, so that children could be with peers with different temperaments and personalities. However, not all psychologists are convinced of the need for such action [12], although in situations in which a child does not have any cousins, such treatments are indicated, especially due to the fact that a post-industrial society requires a high degree of mobility, which results in many people living far away from their families. But the life of a child should not be confined to the realities of school.

The issue of the loneliness of children and young people appears in some Polish publications where researchers have formulated the thesis about the double alienation of modern only children. First, it indicates the generational isolation resulting from technological development, which results in an individual interacting more often with a computer than with a person. Secondly, today, as in the 19th century, the isolation due to being an only child is being emphasized [13]. Other authors, in turn, are convinced that it is precisely the development of modern technology that keeps an only child from risking loneliness, because at any moment they may come in contact with their peers. But reducing interpersonal relationships mainly to the virtual plane can lead to dangerous addictions and phobias.

Another aspect of loneliness, but in the mature age, is the issue related to the care of one's parents. In this case, it is not about financial responsibilities, but, above all, the burden of decision-making, e.g., on the choice of therapy. On the basis of interviews conducted with more than 60 only children, Jill Pitkeathley and David Emerson have argued that the theme causing the largest fear among res- 
pondents is bearing this responsibility alone [1]. Oftentimes, only children do not have close family to ask questions, consult, or discuss topics related to the care of their parents. And if 20 or 30 years ago they could count on relatives, nowadays in the face of the growing scale of being an only child such support becomes unlikely.

Parents of only children also have to face their own challenges. Initially, they must deal with questions from the environment on why they only have one child, as well as stereotypical opinions about only children in a family environment, at school, etc. Over time, new issues emerge, one of which is experiencing one's own old age and communicating this with their only child, but in such a way as to not dominate the child's life with their own. This is not a simple task and requires much preparation. Geragogues, whose task is to assist the elderly in living their age actively and with worth, can be helpful in this matter. And just as educators can help parents in the educational process of their children, geragogues can provide advice in the adult childaged parent relations.

\subsection{Educational Challenges}

The generality of being an only child raises challenges not only with an only child and the child's parents, but also other members of society, such as teachers who play a significant role in the process of school socialization. Currently, the structure of the classroom in terms of having siblings looks quite different than in the 1980s or 1990s. This generates new challenges for teachers, which may result from greater competition among students, as parents often project all their ambitions onto the only child, etc. A Polish teacher is a little helpless against such challenges, as manuals, school reading, and modern-day TV shows do not take into account the current demographic situation in Poland. On public television and major commercial TV stations, there are actually no programs for children, apart from the rarely aired cartoons. In children-themed channels and programs targeting the youngest children, heroes usually have siblings, play with them, and share their joys and concerns. The fact is that today's young generation prefers social networking sites to watching TV programs, but this mainly concerns adolescents and older children. The younger children, who are not yet using the Internet, are missing references to the fact of being only children, including their position in the world of adults.

The growing population of only children also affects the education network. As a result of the demographic decline, a number of outlets have been closed down. In the $1990 / 91$ academic year, there were 20,533 primary schools in Poland; in 2010/11, the number fell to 13,922 . The number of students has also fallen in the past two decades - by about 2 million. In 1990/91, there were 7,516,356 children and adolescents enrolled in Polish schools; in 2011/12, that number was 5,415,723 [14]. This year, approximately 2,300 schools of various types and levels may disappear from the Polish map. The Ministry of National Education is trying to "fill" the schools by lowering the age limit for compulsory education, but this is a shortsighted action. One of the age groups will be very numerous, but the following ones will again be small, mainly because the number of births in Poland is in constant decline. Besides, beginning compulsory education at the age of six years old is a hidden extension for work time for Polish residents. In the case of women, in 2012 time for professional work was extended in total by eight years. Beginning with the $2005 / 06$ academic year, the number of students is also decreasing annually: in the indicated period, there were $1,953,832$; in the $2010 / 11$ academic year, only $1,841,251$ people studied. Eradication of educational institutions contributes to their degradation, especially in small towns. The school, especially in rural areas, often acts as a culture shaper, similarly to higher vocational schools in cities. It's a challenge for local authorities, which should prevent the negative effects of such actions. This is even more difficult because local governments, while making decisions about closing down schools, often face a dilemma: quality of education or the economy.

\subsection{Societal Challenges}

The challenge society faces is how to ensure a decent life in old age for its citizens. This is connected with the proper functioning of the pension system. Declines in fertility and high unemployment rates have begun to undermine the foundations of the pension system. As it stands, the Social Insurance Board does not have the funds necessary for paying pensions: in 2010 a sum of PLN 7.5 billion was taken from the Demographic Reserve Fund for the current provisions; in 2011, it was PLN 4 billion; in 2012, the figure was PLN 2.89 billion. Furthermore, in 2011 the Social Insurance Board received budgetary grants of PLN 37.1 billion and borrowed PLN 5 billion from banks. Furthermore, at any moment the demographic bubble from the 1950 s will begin to retire. In the face of a growing population of only children, this seems downright disastrous. The actions subsequently taken, such as the 1999 pension reform and the increase of the age of retirement to the age of 67 years, did not bring the intended results. Growing levels of unemployment make the situation even worse.

Another problem facing Poland is how to provide care for the elderly. In the cultural circle of which Poland is a part, caring for aging parents is usually the duty of daughters, but the increasing population of only children will cause the current system to become unbalanced. Demographic studies have shown several indicators that describe quantitatively the level of tutelary potential for senior citizens, e.g., nursing potential indicator. According to data from the Central Statistical Office, in 2000 it was 5.1 for Poland, and in the future, i.e., in the year 2050, it will decrease to 1.7 . These trends are also confirmed by the indicators used by the Population Office of the United Nations: in the case of Poland, the rate of care for parents in 1975 was 2.6, but in 2000 it already rose to 6.1 . The increasing 
share of only children is also noticeable in the sphere of religious life, as it has an impact on the number of choosing the religious vocation. As Mother Weronika Sowulewska (a Camaldolese nun) notes, only children faced with the choice of "caring for your parents or for the convent" choose the former. It is true that demographic decline is not the main cause of a vocational decrease, but the generalization of the family model of $2+1$ or even $1+1$ plays some role in it [15].

\section{Summary and Conclusions}

The generality of being an only child contributes to the formation of many challenges both on the macroscale and the microscale. The former should be taken care of by the country by leading a pro-birth social policy, reforming the pension system, and shaping immigration policy. The latter requires individuals to take action. However, these actions must be targeted and based on the results of scientific studies and concepts developed by these studies. Due to the fact that the conditions in which only children function in society have undergone dramatic changes in recent years, new research must be carried out in the area of social sciences. This does not mean the rejection of the conclusions from the last 30 or 40 years concerning the exploration of being an only child. These tests should primarily concern the impact of modern technology on the functioning of only children in the group. It would be useful to compare profiles of only children from the 1980s and 1990 s with contemporary profiles. There is also one more area that draws attention of a small group of researchers: the only child in advanced age. Scientists should also not forget about the issue of only children who become parents. Generally, however, when addressing the issue of only children, researchers cover issues only related to childhood and adolescence, skipping the perspective of more advanced age. Thus, there are bright new areas of research awaiting psychologists, sociologists, pedagogues, andragogues, and other researchers.

Another idea is the examination of only children issues in public discourse, with particular focus given the effects of the growing population of only children on the functioning of a country. Currently, this issue is absent, as reflections on fertility are too abstract for many people. In the discussion, there is no connection between demographic indicators and the individual position of the family unit or the life of local communities. People often do not realize that their personal decisions affect society. But at this point another problem arises: Polish residents are missing the sense of community, and civil society is in the early stages of construction.

\section{References}

[1] J. Pitkeathley, D. Emerson, Only Child. How to Survive Being One, Warszawa: Agencja Wydawnicza Jacek Santorski \& Co: 2007.

[2] Demographic Yearbook of Poland 2012, Warszawa: GUS 2012.

[3] The World Factbook, available on the Internet: https://www.cia.gov/library/publications/the-worldfactbook/rankorder/2127rank.html.

[4] T. Falbo, Your One and Only. Educational psychologist dispels myths surrounding only children [online], available on the Internet: http://www.utexas.edu/features/archive/ 2004/single.html.

[5] Understanding Society. Tracking the lives and attitudes of 40,000 households [online], available on the Internet: https://www.iser.essex.ac.uk/understanding-society.

[6] D. Downey, Siblings help children get along with others in kindergarten [online], available on the Internet: http://researchnews.osu.edu/archive/socskill.htm.

[7] M. Grose, Why First-Born rule the World and Last-Born want to change it, Australia: Radom House 2003.

[8] J. Rembowski, Jedynactwo dzieci w domu i w szkole, Wrocław: Zakład Narodowy im. Ossolińskich 1975.

[9] J. Śledzianowski, Jedynak w życiu małżeńskim i w rodzinie, Kielce: Agencja Wydawniczo-Poligraficzna "Rubikon" 1992.

[10] M. Tyszkowa, Badania nad uspołecznieniem i osobowością dzieci jedynych i mających rodzeństwo, In: Rozwój dziecka w rodzinie i poza nią, pod. red M. Tyszkowej, Poznań: UAM, Poznań 1985, p. 53.

[11] The message from CBOS studies, SB/61/2012, Reproductive needs and preferred and implemented family model, available on the Internet: http://www.cbos.pl/SPISKOM.POL/2012/K_061_12.PDF.

[12] S. Newman, Parenting an Only Child: The Joys and Challenges of Raising Your One and Only, New York: Broadway Books 1990.

[13] M. Pęczak, Adrenalina pokoleń, Arkadia No 8/2000.

[14] Education in 2011/2012 School Year, Warszawa 2012, available on the Internet: http://www.stat.gov.pl/cps/rde/xbcr/gus/e_oswiata_i_wycho wanie_2011-2012.pdf.

[15] K. Czaczkowska, Czy żeńskie klasztory opusztoszeją? [online], "Rzeczpospolita", available on the Internet: http://www.rp.pl/artykul/804402-Czy-zenskie-klasztoryopustoszeja.htm. 